Saudi Journal of Medical and Pharmaceutical Sciences

Abbreviated Key Title: Saudi J Med Pharm Sci

ISSN 2413-4929 (Print) |ISSN 2413-4910 (Online)

Scholars Middle East Publishers, Dubai, United Arab Emirates

Journal homepage: http://scholarsmepub.com/sjmps/

Case Report

\title{
Recurrence of Juvenile Nasopharyngeal Angiofibroma Treated by Radiotherapy: A Case Report
}

Mazouz K*, laatitioui S, Abourazeq H, Barkich S, Saadoun M, EL Matlini A, Raouah M, bouchabaka Y, Idrissi Z, Darfaoui M, lalya I, Elomrani A, KHouchani M

Radiation Oncology Department, Mohammed VI University Hospital, Marrakech

DOI: $10.36348 /$ sjmps.2019.v05i12.021

| Received: 19.12.2019 | Accepted: 26.12.2019 | Published: 30.12.2019

*Corresponding author: Mazouz $\mathrm{K}$

\section{Abstract}

Juvenile Nasopharyngeal Fibroma (J.N.A) is a rare nasopharyngeal tumor that affects male adolescents; it is a benign but locally aggressive vascular tumor due to invasion of adjacent structures. The symptomatology is not very specific; but predominated by epistaxis. His treatment is essentially surgery; however, the use of other therapeutic means: radiotherapy, interventional arteriography, chemotherapy and hormone therapy are of value in the case of locally unresectable advanced tumors. Through our observation of a case of nasopharyngeal fibroma, we discuss the clinical, radiological and histological aspects as well as the therapeutic management of these tumors.

Keywords: Juvenile, Nasopharyngeal, Radiotherapy.

Copyright @ 2019: This is an open-access article distributed under the terms of the Creative Commons Attribution license which permits unrestricted use, distribution, and reproduction in any medium for non-commercial use (NonCommercial, or CC-BY-NC) provided the original author and source are credited.

\section{INTRODUCTION}

Juvénil nasopharyngeal angiofibroma (JNA) is a rare nasopharyngeal tumor that accounts for only $0.05 \%$ of head and neck tumors [1]. Despite a benign histological appearance, this tumor may have a vital and functional prognosis due to its rich vascularization and its ability to invade adjacent structures, endocranial extension was reported in 10\% [2]. MRI without and with injection of gadolinium confirms the character hypervascularized lesion, and precise soft tissue extension. The angio IRM targets the foster vessels of the tumor. Histological, JNA is an uncapsed tumor consisting of endothelial cells embedded in a fibrous stroma rich in collagens [3]. Surgical extirpation of JNA is the treatment of choice in the vast majority of patients; but there are no consensus recommendations on the therapeutic management of the locally incumbent JNA $[4,5]$.

\section{OBSERVATION}

A 16-year-old boy presented with right-sided nasal obstruction for 6 months and recurrent episodes epistaxis for 1 month, with ipsilateral hypoacusis.the endoscopic examination objectified a tissue mass at the expense of the postero-superior part of the right nasal fossa. A facial computed tomographic scan (Figur 1) revealed an enhancing mass occupying the right nasal cavity, the nasopharynx, and extending into the pterygopalatine fossa and the sphenoid sinus, complemented by cervico-facial angio-MRI shows a voluminous nasopharyngeal tissue process with sphenoidal extension and deep spaces of the face in favor of a nasopharyngeal fibroma. Angiography revealed that feeding vessels to the mass werefrom the internal maxillary artery and meningeal branches of the right internal carotid artery, both of which were embolized. The mass was completely excised and the anatomopathological study retained the diagnosis by objectifying a dense fibroblastic proliferation made of fibroblast, without atypies or mitoses the fibrous matrix is abundant with numerous congestive vessels. The patient is put under surveillance with alternance cavoscopy / MRI facial every 3 months. 1 year later the patient reconsults for recurrence of the symptomatology; a facial angio-IRM (Figure 2) performed a nasopharyngeal tissue and right nasal fossa process measuring $33 * 35 * 28 \mathrm{~mm}$ in T1 hypo intense, hyper intense $\mathrm{T} 2$, raised heterogeneously after gadolinium injection. This process is centered on the pterygopalatine cleft with extension towards the infratemporal fossa, also fills the homolateral sphenoid sinus with endocranial extension, it fills the sphenoidal fissure as well as the inferior orbital fissure. This process is vascularized by branches of the right internal maxilla.this hypervascularized process is compatible with a recurrence nasopharyngeal fibroma. The patient has benefited from local radiotherapy because of the 
non-resecability of this process; a customized thermoplastic cast was used for immobilization. A CT simulation scanner with $3 \mathrm{~mm}$ slice thickness was using. The Gross tumor volume (GTV) was delineated as evident on the planning CT scan. An isotropic expansion of $5 \mathrm{~mm}$ was added to form the Planning target volume (PTV). The planning was done using treatment planning system version 9.0 for threedimensional conformal technique (3DCRT). The PTV received a dose of $54 \mathrm{GY}$, in 27 sessions of $1.8 \mathrm{~Gy}$. The evolution was marked by a radio-clinical stability and the patient was asymptomatic at 12 months' follow-up.

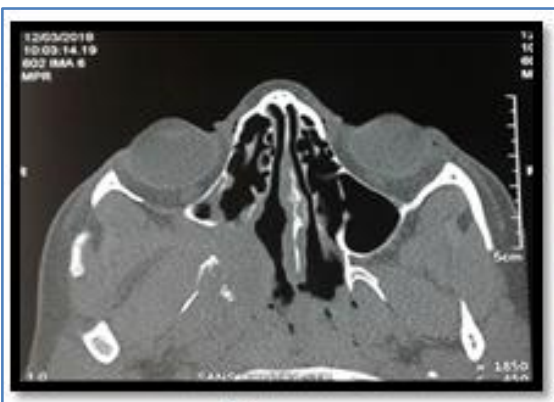

a.

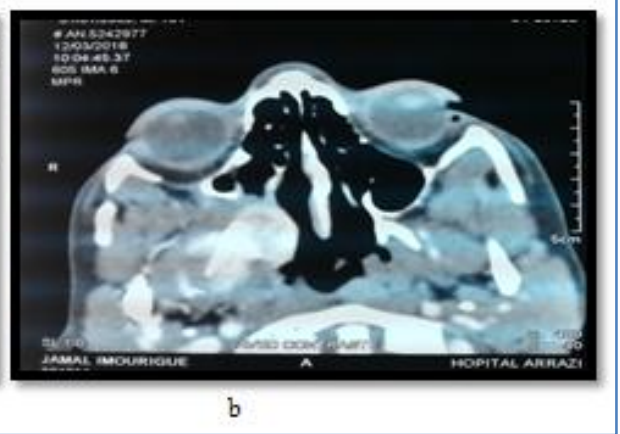

Fig-1: Facial CT: without (a) and with injection (b) of PDC: right nasopharyngeal tumors infiltrating pterygopalatine fossa, ptergoide muscles

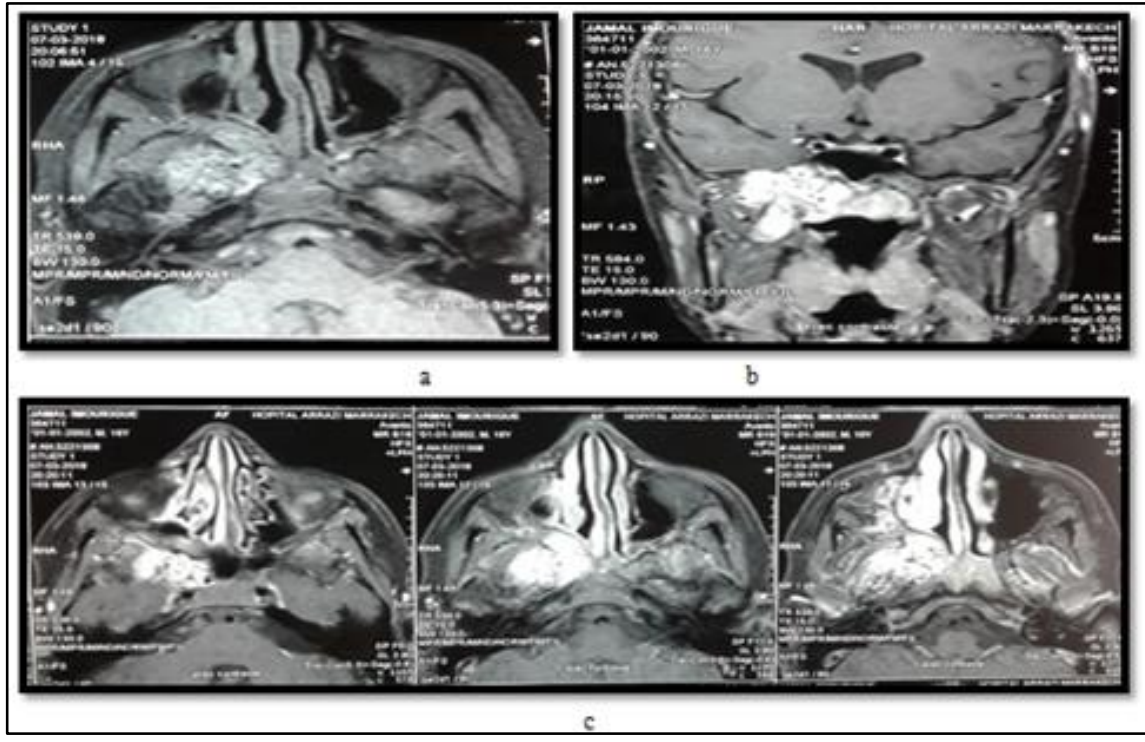

Fig-2: Facial angio-IRM: Nasopharyngeal tissue and right nasal fossa process measuring $33 * 35 * 28 \mathrm{~mm}$ in $\mathrm{T} 1 \mathrm{hypo}$ intense (A), hyper intense T2 (B, C), raised heterogeneously after gadolinium injection $(A)$. This process is centered on the pterygopalatine cleft with extension towards the infratemporal fossa, also fills the homolateral sphenoid sinus with endocranial extension, it fills the sphenoidal fissure as well as the inferior orbital fissure

\section{DISCUSSION}

Juvenile angiofibroma (JA) is a rare benign vascular tumor that accounts for only $0.05 \%$ of all head and neck tumors $[4,6]$, and which typically affects male adolescents between 9 and 19 years old; some cases of JNA of women were reported in the literature [7]. The incidence of these tumors appears to be much higher in the Middle East and India than in Europe [4, 8].

JNA appears as a general rule in the posterior part of the lateral wall of the nasal fossa near the upper edge of the sphenopalatin foramen. The analysis of 46 cases indicates that angiofibroma may take origin in the pterygoid canal [9]; then invade the pteryopalatine fossa and rather the surrounding tissue: the bone, the orbit, the infratemporal fossen and the base of the skull [10].
The most common reason for consultation is recurrent epitasis associated with nasal obstruction. The symptoms are first unilateral then can become bilateral. In locally advanced forms there may be facial pain with swelling, orbital involvement with decreased visual acuity, anosmia, rhinolalia and earache may be observed [12,13].

Before this clinical picture, a nasofibroscopy is indicated; showing a large lobulated mass hyper vascularized at the expense of the nasal cavity. Biopsy should be avoided, given the risk of haemorrhage, except in front of an atypical table (female sex, advanced age)[14]. 
CT and MRI is more than a diagnostic tool, they allow refining the assessment of local extension, but especially playing a key role in the evaluation of pretreatment and preoperative planning and postoperative surveillance $[15,16]$.

Computed tomography, objective the appearance of a Tissue density mass of interest to the nasal cavity and the nasopharynx, enhancing intensely after injection of contrast [15, 17]. MRI provides a better assessment of the extension to the deep spaces of the face, and endocranial invasion; the JNA appears in the form of a mass in discrete hypo signal in $\mathrm{T} 1$ and in hypersignal in $\mathrm{T} 2$ with intense enhancement after Gadolinium injection.Although angio-MR may help in the vascular assessment, and is indispensable to appreciate blood supply of JNA [15, 10]. Also, Angiography can be used to assess the arteries involved in tumor vascularization; provided generally by the ipsilateral maxillary artery. It is especially indicated to guide an embolization in order to avoid perioperative bleeding which can be fatal for the patient [18].

Histologically, NJA is composed of a fibrous stroma rich in collagen and fibroblasts containing vascular structures of different sizes [3]. The expression of sex hormone receptors has been demonstrated in tumor tissues. The effect of androgens and estrogen seems to influence the development of the disease [3, $11]$

Amongst the various stadification scales of the proposed JVAs, the most widely used in the recent literature is Radkowski's classification, which has made it possible to underline the various modes of tumor extension [19].

Table-1: Classification of JNA by Radkowski [20]

\begin{tabular}{|l|l|}
\hline Stade & Description des extensions tumorales \\
\hline \multirow{5}{*}{ I } & $\begin{array}{l}\text { IA: Atteinte limitée à la cavité nasale et au } \\
\text { nasopharynx } \\
\text { IB: idem + envahissement de 1 ou } \\
\text { plusieurs sinus }\end{array}$ \\
\hline II & $\begin{array}{l}\text { IIA: Envahissement minime à travers le } \\
\text { foramen sphénopalatin et dans la partie } \\
\text { médiane de la FPP } \\
\text { IIB: Comblement de la FPP refoulant la } \\
\text { paroi postérieure du sinus maxillaire vers } \\
\text { l'avant, érosion orbitaire, refoulement des } \\
\text { branches de l'artère maxillaire interne } \\
\text { IIC: Envahissement de la fosse } \\
\text { infratemporale, de la joue, ou en arrière } \\
\text { des apophyses ptérygoïdes }\end{array}$ \\
\hline III & $\begin{array}{l}\text { Erosion de la base du crâne } \\
\text { IIIA: Envahissement intracrânien minime } \\
\text { IIIB: Envahissement intracrânien massif } \\
\text { ou du sinus caverneux }\end{array}$ \\
\hline
\end{tabular}

Surgery and external radiotherapy are the therapeutic modalities of choice, the indication of which depends on the local extension of the tumor and its clinical stage $[15,21]$.

In localized stages, surgical excision is the recommended therapeutic modality, and should be preceded; $24 \mathrm{~h}$ to $48 \mathrm{~h}$, by embolization to limit the risk of revascularization or development of a collateral vascular [22]. The endoscopic approach has reduced the rate of complications and comorbidities while ensuring good local control [23]. The indications of the external track (lateral rhinitomy, transpalatin track, Fort track 1 and track first lateral of the infratemporal fossa) became rare.

The presence of recurrent and residual tumor after surgery or intracranial extension of. Tumor was taken as criteria for radiation therapy. It is recommended a total dose irradiation between 30 and $50 \mathrm{~Gy}$ in conventional spreading, of 1.8 to 2 Gy per session, five sessions per week [24]. In a review, Reddy et al. reported the efficacy of radiation in 10 patients with intracranial extension [25, 24]. The authors reported $85 \%$ local control, after a median follow up of 2.5 years. The published series have shown promising results in JNA treated with intensity modulated radiotherapy (IMRT) [25, 28]. The local control was greater than $70 \%-100 \%$ with respect for organs at risk $(29,30)$.

A very significant regression of tumor size was reported after chemotherapy combining adriamycin and dacarbazine [29], or hormone therapy based on testosterone receptor inhibitors [30]; but this alternative is supported by only a few reports. 
Residual tumor screening can be performed by early imaging within 48 hours of surgery. With CT injected or MRI. Early surgical revision can be performed quickly endoscopically, in case of tumor residue. Imaging is performed every 3 months and then 6 months in the first two years and then an annual follow-up. The finding of a post-surgical residual, or a recurrence treated by radiotherapy leads to closer monitoring, in the absence of evolution and in case of stability, therapeutic abstention is the rule, and the remainder is simply monitored. The imaging is each time completed by an endoscopic examination in consultation [31].

\section{CONCLUSION}

Juvenil Nasopharyngeal angifibroma must be evoked in front of any unilateral nasal obstruction associated or not with an epistaxis because the early diagnosis allows a suitable treatment by endoscopic or more rarely surgical resection. Additional or exclusive radiotherapy in the cases advanced locally must be a subject of research for clarifies its role in long-term local control.

\section{RÉFÉRENCES}

1. Gullane, P. J., Davidson, J., O'Dwyer, T., \& Forte, V. (1992). Juvenile angiofibroma: a review of the literature and a case series report. The Laryngoscope, 102(8), 928-933.

2. Jafek, B. W., Krekorian, E. A., Kirsch, W. M., \& Wood, R. P. (1979). Juvenile nasopharyngeal angiofibroma: management of intracranial extension. Head \& neck surgery, 2(2), 119-128.

3. Schuon, R., Brieger, J., Heinrich, U. R., Roth, Y., Szyfter, W., \& Mann, W. J. (2007). Immunohistochemical analysis of growth mechanisms in juvenile nasopharyngeal angiofibroma. European archives of oto-rhinolaryngology, 264(4), 389-394.

4. Nicolai, P., Schreiber, A., \& Bolzoni Villaret, A. (2011). Juvenile angiofibroma: evolution of management. International journal of pediatrics, 2012.

5. Enepekides, D. J. (2004). Recent advances in the treatment of juvenile angiofibroma. Current opinion in otolaryngology \& head and neck surgery, 12(6), 495-499.

6. Lund, V. J., Stammberger, H., Nicolai, P., Castelnuovo, P., Beal, T., Beham, A., ... \& Cavallo, L. (2010). European position paper on endoscopic management of tumours of the nose, paranasal sinuses and skull base. Rhinology. Supplement, 22, 1-143.

7. Patrocinio, J. A., Patrocinio, L. G., Borba, B. H. C., Bonatti, B. D. S., \& Guimarães, A. H. B. (2005). Nasopharyngeal angiofibroma in an elderly woman. American journal of otolaryngology, 26(3), 198-200.
8. Maran. A. G. D., \& Lund, V. J.(1990). "Nasal physiology," in ClinicalRhinology, A. G. D. Maran and V. J. Lund, Eds., 5, Georg Thieme, Stuttgart, Germany.

9. Seo, C. S., Han, M. H., Chang, K. H., \& Yeon, K. M. (1996). Angiofibroma confined to the pterygoid muscle region: $\mathrm{CT}$ and $\mathrm{MR}$ demonstration. American journal of neuroradiology, 17(2), 374-376.

10. Liu, Z. F., Wang, D. H., Sun, X. C., Wang, J. J., Hu, L., Li, H., \& Dai, P. D. (2011). The site of origin and expansive routes of juvenile nasopharyngeal angiofibroma (JNA). International journal of pediatric otorhinolaryngology, 75(9), 1088-1092.

11. Gatalica, Z. (1998). Immunohistochemical analysis of steroid hormone receptors in nasopharyngeal angiofibromas. Cancer letters, 127(1-2), 89-93.

12. Maniere, C., Cognard, J. L., Badet, J. M., \& Chobaut, J. C. (1993). Le fibrome nasopharyngien. JFORL, 42(2), 1091-5.

13. Belcadhi, M., Mani, R., Harzallah, M., Bouaouina, N., \& Bouzouita, K. (2008). Nasopharyngeal angiofibroma with intracranial extension: Situating the chemotherapy-radiotherapy association. Cancer radiotherapie: journal de la Societe francaise de radiotherapie oncologique, 12(5), 385-388.

14. Scholfield, D. W., Brundler, M. A., McDermott, A. L., Mussai, F., \& Kearns, P. (2016). Adjunctive treatment in juvenile nasopharyngeal angiofibroma: how should we approach recurrence?. Journal of pediatric hematology/oncology, 38(3), 235-239.

15. Oueslati, S., Gamra, O. B., Kharrat, S., Sassi, S., Milka, N., Rajhi, H., \& Mnif, N. (2008). Le fibrome nasopharyngien: à propos de 15 cas traités par embolisation. Journal de radiologie, 89(5), 579-584.

16. Oueslati, S., Gamra, O. B., Kharrat, S., Sassi, S., Milka, N., Rajhi, H., \& Mnif, N. (2008). Le fibrome nasopharyngien: à propos de 15 cas traités par embolisation. Journal de radiologie, 89(5), 579-584.

17. Bohman, L., ManCuso, A., Thompson, J., \& Hanafee, W. (1981). CT approach to benign nasopharyngeal masses. American Journal of Roentgenology, 136(1), 173-180.

18. Rzaev, R. M. (2007). The role of angiography in diagnosis and surgical treatment of patients with juvenile angiofibroma of the nasopharynx. Vestnik otorinolaringologii, (4), 18-22.

19. Onerci, M., Oğretmenoğlu, O., \& Yücel, T. (2006). Juvenile nasopharyngeal angiofibroma: a revised staging system. Rhinology, 44(1), 39-45.

20. Radkowski, D., McGill, T., Healy, G. B., Ohlms, L., \& Jones, D. T. (1996). Angiofibroma: changes in staging and treatment. Archives of Otolaryngology-Head \& Neck Surgery, 122(2), 122-129. 
21. Enepekides, D. J. (2004). Recent advances in the treatment of juvenile angiofibroma. Current opinion in otolaryngology \& head and neck surgery, 12(6), 495-499.

22. Yamada, M., Tsunoda, A., Tokumaru, T., Aoyagi, M., Kawano, Y., Yano, T., \& Kishimoto, S. (2014). Surgery for juvenile nasopharyngeal angiofibroma with lateral extension to the infratemporal fossa. Auris Nasus Larynx, 41(4), 359-363.

23. Liu, J. K., Husain, Q., Kanumuri, V., Khan, M. N., Mendelson, Z. S., \& Eloy, J. A. (2016). Endoscopic graduated multiangle, multicorridor resection of juvenile nasopharyngeal angiofibroma: an individualized, tailored, multicorridor skull base approach. Journal of neurosurgery, 124(5), 13281338.

24. Reddy, K. A., Mendenhall, W. M., Amdur, R. J., Stringer, S. P., \& Cassisi, N. J. (2001). Long-term results of radiation therapy for juvenile nasopharyngeal angiofibroma. American journal of otolaryngology, 22(3), 172-175.

25. Mallick, S., Benson, R., Bhasker, S., \& Mohanti, B. K. (2015). Conformal radiotherapy for locally advanced juvenile nasopharyngeal angiofibroma. Journal of cancer research and therapeutics, 11(1), 73.

26. Beriwal, S., Eidelman, A., \& Micaily, B. (2003). Three-dimensional conformal radiotherapy for treatment of extensive juvenile angiofibroma: report on two cases. ORL, 65(4), 238-241.
27. Chakraborty, S., Ghoshal, S., Patil, V. M., Oinam, A. S., \& Sharma, S. C. (2011). Conformal radiotherapy in the treatment of advanced juvenile nasopharyngeal angiofibroma with intracranial extension: an institutional experience. International Journal of Radiation Oncology* Biology* Physics, 80(5), 1398-1404.

28. Kuppersmith, R. B., Teh, B. S., Donovan, D. T., Mai, W. Y., Chiu, J. K., Woo, S. Y., \& Butler, E. B. (2000). The use of intensity modulated radiotherapy for the treatment of extensive and recurrent juvenile angiofibroma. International journal of pediatric otorhinolaryngology, 52(3), 261-268.

29. Goepfert, H., Cangir, A., \& Lee, Y. Y. (1985). Chemotherapy for aggressive juvenile nasopharyngeal angiofibroma. Archives of Otolaryngology, 111(5), 285-289.

30. Gates, G. A., Rice, D. H., Koopmann Jr, C. F., \& Schuller, D. E. (1992). Flutamide-induced regression of angiofibroma. The Laryngoscope, 102(6), 641-644.

31. Nicolai, P., Villaret, A. B., Farina, D., Nadeau, S., Yakirevitch, A., Berlucchi, M., \& Galtelli, C. (2010). Endoscopic surgery for juvenile angiofibroma: a critical review of indications after 46 cases. American journal of rhinology \& allergy, 24(2), e67-e72. 